\title{
INDONESIAN INTERPRETATION OF THE QUR'AN ON KHILĀFAH The Case of Quraish Shihab and Yudian Wahyudi on Qur'an 2: 30-38
}

\section{Djidin*; Sahiron Syamsuddin**}

* State Institute for Islamic Studies (IAIN) Ternate; **Sunan Kalijaga State Islamic University (UIN) Yogyakarta email:djidin.ternate@gmail.com

\section{Abstract}

Today the issue of building al-khiläfah al-islamiyah (Islamic Caliphate) has been raised by Hizbut Tabrir Indonesia (HTI). One of its arguments is that it is obligatory, because Qur'an, 2:30 mentions the term khalifah. However, this argument has been questioned by many Muslim scholars. Some of them are Quraish Shihab and Yudian Wabyudi. In this article a comparative study is conducted in such a way we can provide readers with a 'direct' comparasion between Shibab's and Wabyudi's thoughts. The emphasis of their differences is shown more clearly than their similarities. Some important points that are discussed here are their interpretations of Qur'an, 2: 30-38. After analyzing their statements expressed in their writings and interviews, we have found that both have the same idea that Qur'an, 2: 30 does not talk about the Islamic Caliphate, and therefore, it cannot be used as an argument for its building. We have also found that they have exegetical differences that might refer to the fact that Shihab has much emphasis on the 'bistorical meaning' of the verses, whereas Wabyudi prefers their 'significance' for human beings. Wacana khilafah Islam di Indonesia menguat seiring dengan kehadiran Hizbut Tahrir Indonesia (HTI). Salas satu argumen mereka adalah adanya istilah khalifah dalam Qur'an, 2: 30. Namun argument tersebut justru menjadi persoalan bagi pemikir muslim lainnya, dua diantaranya Quraish 
Shibab dan Yudian Wahyudi. Dalam tulisan ini diharapkan pembaca dapat melihat secara langsung perbandingan dua pemikiran tersebut. Beberapa point penting yang diperdebatkan adalah tafsir ayat Qur'an, 2: 30-38. Berdasarkan analisis pada karya tulis dan wawancara, keduanya samasama menunjukkean bahwa ayat tersebut di atas tidak membahas al-khiläfah al-islamiyah. Meskipun keduanya sependapat, masing-masing memberikan tekanan yang berbeda dimana Shibab lebih ke makna historis, sedangkan Wabyudi condong ke signifikasi bagi kemanusiaan.]

Keywords: Caliphate, Hizb al-Tahrīir, Quraish Shihab, Yudian Wahyudi, exegesis

\section{A. Introduction}

Qur'an 2: 30 is one of Qur'anic verses used by the Hizb al-Tahrīr to argue for its political interest in re-building the Islamic chaliphate. However, the question is whether the verse that consists of, among others, the word khalifa really deals with it. It has been interpreted by many scholars from the past until now. They point out that it does not refer to the idea that has been proposed by the organisation. For example, al-Husayn ibn Muḥammad al-Dāmaghānī in his work Ișlāh al-Wujūh wa al-Naz̧a'ir that the word means badalan min man mada min al-jinni (successor of the jinns who had passed away [from their cultivating the earth]). ${ }^{1}$ So, for him, the verse does not deal with the establishment of Islamic state. Similar opinions are expressed by many other interpreters.

In the Indonesian context, many experts have also contibuted to this discourse. However, in order that this article is focused, we discuss here the interpretations proposed by Quraish Shihab and Yudian Wahyudi. At least, there are two reasons why we choose these scholars. First, they are experts in Qur'an exegesis. Shihab wrote some exegetical works, such as Tafsir al-Mishbah and Al-Qur'an dan Maknanya (the Qur'an and its Meaning), and many books on the Qur'an, such as Membumikan Al-Qur'an. Wahyudi's works vary in terms of their subject matters. His dissertation that was written in McGill University deals with, among others, the Qur'anic hermeneutics proposed by Muhammad 'Ābid alJābirī, Hasan Hanafĩ and Nurcholish Madjid. He also wrote many books

1 See al-Husayn ibn Muhammad al-Dāmaghānī, Ișlāḥ al-Wujūh wa al-Nažāir (Beirut: Dar al-'ilm, 1970), p. 162. 
and articels on Islamic studies in general. Some of them are published in English and some in Indonesian. Second, in some cases, they have proposed new ideas in the field of Qur'an interpretation. In our prior research, we have found that Wahyudi interpreted some Qur'anic verses in a new 'symbolic' perspective and in such a way they should be applied in the lives of Muslims. New ideas can also be found in Shihab's works.

In this article a comparative study is conducted in such a way we can provide readers with a 'direct' comparasion between Shihab's and Wahyudi's thoughts. The emphasis of their differences is shown more clearly than their similarities. Some important points that are discussed here are their interpretations of Qur'an 2: 30-37 and certain factors that are probably relevant to them and some exegetical implications. Before these points are discussed, short biographies of the two scholars will be presented, so that readers will know in more details.

\section{B. Short Biographies in Comparison}

Shihab and Wahyudi differ in many ways as illustrated below. Shihab was born in Rampang, South Sulawesi, on February 16, 1944, while Wahyudi was born in Balikpapan, East Kalimantan, on April 17, 1960. ${ }^{2}$ Shihab comes from an educated Arab family because his father, Abdurrahman Shihab, is a professor in the field of interpretation, even successful businessman and politician in South Sulawesi. ${ }^{3}$ On the other hand, Asmin Prajabangsa, Wahyudi's father, was an army (army) from Banyumas, Central Java, which was assigned to Balikpapan in 1947/1948. His main direct task is to defend the oil refinery in Sangasanga. ${ }^{4}$

${ }^{2}$ Yudian Wahyudi, Jihad Ilmiah: Dari Tremas ke Harvard, 4th edition (Yogyakarta: Pesantren Nawesea Press, 2018), p. 231; Yudian Wahyudi, Jihad Ilmiah Dua: Dari Harvard, Yale, dan Princeton, 4th edition (Yogyakarta: Pesantren Nawesea Press, 2017), p. 227; Yudian Wahyudi, Dari McGill ke Oxford Bersama Ali Shari'ati dan Bint al-Shati, 2nd edition (Yogyakarta: Pesantren Nawesea Press, 2016), p. 95.

${ }^{3}$ Shihab's biography is mostly derived from his official website: 'About', Muhammad Quraish Shibab Official Website, http://quraishshihab.com/about/, accessed 30 Jan 2017; 'Biografi M. Quraish Shihab', Tafsir Al-Mishbah - M. Quraish Shibab (27 Dec 2010), https://tafsiralmishbah.wordpress.com/biografi-m-quraish-shihab/, accessed 1 Feb 2017.

4 Yudian Wahyudi, interview (18 Feb 2018); Wahyudi, Jihad Ilmiah, pp. xviiixxxiv; Wahyudi, Jihad Ilmiah Dua: Dari Harvard, Yale, dan Princeton, p. 227; Wahyudi, Dari 
Abdurrahman had a contribution in the field of higher education in Makassar: rector of the Indonesian Muslim University (UMI, the largest private university in eastern Indonesia) in 1959-1965 and rector of IAIN Alauddin in 1972-1977. ${ }^{5}$ Asmin, on the other hand, was active as a village cleric: initiated the construction of Darussalam mosque in Klandasan Ilir village, Balikpapan, imam and khatib, led tablil (traditional religious ritual of prayer for the dead), even buried the dead because he was the grandson of a kyai, who was forced to flee to Banyumas with Pangeran Diponegoro captured by the Dutch in $1830 .^{6}$

Shihab completed his basic education in Makassar, ${ }^{7}$ while Wahyudi was in Pacitan, not in his hometown. ${ }^{8}$ Shihab continued his secondary education in Malang, East Java, while 'nyantri' (studied Islam) at the AlFaqihiyyah Islamic Boarding School in Darul Hadits, ${ }^{9}$ whereas Wahyudi continued to Pondok Pesantren (Islamic boarding school) of Tremas (1973-1978) and Pondok Krapyak (Madrasah Al-Munawwir, 1978-1979). At the time of graduation from Islamic junior high school at Tremas (1976) and Madrasah Aliyah (Islamic senior high school) at Al-Munawwir (1979), Wahyudi won the first place award (even after only three months in the first level at Tremas he jumped to the second level). ${ }^{10}$ In 1958, Shihab left for Cairo, Egypt. He was accepted in the second level of al-Madrasa

McGill ke Oxford Bersama Ali Shari'ati dan Bint al-Shati’, p. 227.

5 See.'About'; 'Biografi M. Quraish Shihab'.

${ }^{6}$ Yudian Wahyudi, interview (18 Feb 2018); Yudian Wahyudi, Perang Diponegoro: Tremas, SBY dan Ploso, 3rd edition (Yogyakarta: Pesantren Nawesea Press, 2014), p. 25.

7 See.'About'; 'Biografi M. Quraish Shihab'.

8 Wahyudi went to a school in the Madrasah Ibtidaiyah (elementary Islamic school) Darutta'lim, Damung village in Balikpapan up to grade 4 (1967-1970) because he moved to Sekolah Dasar Negeri (State elementary school) 55 in Jalan Baru, Balikpapan in 1970. He did not go up to the fifth grade/level because he was naughty. Because of his unstoppable delinquency, he was sent to the Tremas Islamic Boarding School in Arjosari, Pacitan, East Java (December 25, 1972). In the evening I studies Islam and in the morning went to an elementary school at Tremas, the village where President Susilo Bambang Yudhoyono was born.

9 See.'About'; 'Biografi M. Quraish Shihab'.

${ }^{10}$ Wahyudi, Jihad Ilmiah, p. 231; Wahyudi, Jihad Ilmiah Dua: Dari Harvard, Yale, dan Princeton, p. 227; Wahyudi, Dari McGill ke Oxford Bersama Ali Shari'ati dan Bint al-Shati', p. 95; Yudian Wahyudi, interview (18 Feb 2018). 
al-Thanawiya in Al-Azhar. ${ }^{11}$ On the other hand, Wahyudi really wanted to go to Al-Azhar University, but his father did not allow it. "Egypt is at war with Israel. During the war there are many stray bullets, even though stray bullets did not know you. It is enough for the father to experience (as an army). My children, especially you, should not experience it." ${ }^{12}$

In 1967, Shihab won the Lc title. (French B.A.; undergraduate level) from Qur'an Interpretation and Hadith Studies Department of the Faculty of Ușūl al-Dīn, Al-Azhar University, ${ }^{13}$ while Wahyudi won B.A. and the Drs. (doctorandus) (at the Duch level for M.A.) from the Shariah Faculty of Sunan Kalijaga State Islamic Instutute (IAIN) of Yogyakarta in 1982 and 1987. He also won B.A. from the Faculty of Philosophy at Gajah Mada University in 1986 and did "Kuliah Kerja Nyata (a field course for community development) (?). ${ }^{14}$ In 1969 Shihab won the M.A. from the same faculty in the field of Qur'an interpretation with the thesis "Al-I'jaz al-Tasyrici li Al-Quran al-Karim". ${ }^{15}$ On the other hand, Wahyudi received the M.A. degree from McGill University, Montreal, Canada, in 1993 with a thesis "Hasbi's Theory of Ijtihad in the Context of Indonesian Fiqh". ${ }^{16}$

Upon his return from Cairo to Makassar, Shihab was appointed to be vice-rector who was in charge for academic and student Affairs of Alauddin Institute of Islamic Studies (IAIN Alauddin), coordinator of Private Universities (Region VII of Eastern Indonesia) and assistant chief of Police of East Indonesia in the field of mental development. He also had carried out various research with themes, among others, "Application of Religious Harmony in East Indonesia" (1975) and "South Sulawesi Waqf Problems" (1978) ${ }^{17}$ On the other hand, upon returning

11 See.'About'; 'Biografi M. Quraish Shihab'.

12 Wahyudi, Jihad ilmiah, p. xxxiv.

13 'About'; 'Biografi M. Quraish Shihab'.

14 Wahyudi, Jihad Ilmiah, p. 231; Wahyudi, Jihad Ilmiah Dua: Dari Harvard, Yale, dan Princeton, p. 227; Wahyudi, Dari McGill ke Oxford Bersama Ali Shariati dan Bint alShati, p. 95.

15 See 'About'; 'Biografi M. Quraish Shihab'.

16 Wahyudi, Dari McGill ke Oxford Bersama Ali Shari'ati dan Bint al-Shati, p. 95; Yudian Wahyudi, 'Hasbi's Theory of Ijtihad in the Context of Indonesian Fiqh.', Ph.D. Dissertation (Montreal: McGill University, 1993).

17 See 'About'; 'Biografi M. Quraish Shihab'. 
from Montreal to Yogyakarta in 1993, Wahyudi had not held a structural position at his campus. He used "free time" as a young lecturer by continuing the translation he had begun since 1982. Wahyudi shifted from the translation of Arabic books to that of English ones into Indonesian. He even took an English course for the TOEFL again and French course. He also taught in Yogyakarta (Cokroaminoto University and Student Islamic Studies Institute) and Surakarta (STAIN and Cakradonya Da'wah College) in addition to his own campus. ${ }^{18}$

In 1980, Shihab continued his doctorate at Al-Azhar, ${ }^{19}$ whereas Wahyudi continued his doctorate to McGill in $1995 .{ }^{20}$ In just two years, Shihab, with the title of his dissertation "Naẓm al-Durar li al-Biqa'i: Tahqiq wa Dirāsah", won a doctorate degree in the field of Qur'anic sciences, with the title cum laude accompanied by the first level of award (mumtār. ma'a al-sharaf al-ūta). ${ }^{21}$ On the other hand, Wahyudi earned his Ph.D. with a dissertation "'The Slogan Back to the Qur'an and the Sunna': Comparative Responses of Hasan Hanafi, Muhammad Abid al-Jabiri and Nurcholish Madjid" in 2002..2 During his doctoral program, Wahyudi became chair of the Canadian Indonesian Student Association (1997), the Founding President of the Indonesian Academic Society (19981999), translated French, English and Arabic works into Indonesian ${ }^{23}$, and presented articles in international conferences held in five continents

18 Wahyudi, Jihad Ilmiah, p. 231; Wahyudi, Jihad Ilmiah Dua: Dari Harvard, Yale, dan Princeton, p. 227; Wahyudi, Dari McGill ke Oxford Bersama Ali Shariati dan Bint alShati', p. 95.

19 See 'About'; 'Biografi M. Quraish Shihab'.

20 Wahyudi, Jihad Ilmiah, p. 231; Wahyudi, Jihad Ilmiah Dua: Dari Harvard, Yale, dan Princeton, p. 227; Wahyudi, Dari McGill ke Oxford Bersama Ali Shariati dan Bint alShati', p. 95.

21 See 'About'; 'Biografi M. Quraish Shihab'.

22 Yudian Wahyudi, "The Slogan "Back to the Qur'an and the Sunna": A Comparative Study of the Responses of Hasan Hanafi, Muhammad 'Abid al-Jabiri and Nurcholish Madjid', PhD. Dissertation (Montreal: McGill University, 2002).

23 The number of translations during twenty years (1982-2002) is 53 books. See Wahyudi, Dari Tremas ke Harvard, p. 231; Wahyudi, Dari Harvard ke Yale dan Princeton, p. 227; Wahyudi, Dari McGill ke Oxford: Bersama Ali Shari'ati dan Bint al-Shati, p. 95. 
(1997-2001). The presented papers were then published in America ${ }^{24}$, Europe (three in Oxford: Oxford University Press, ${ }^{25}$ Blackwell, ${ }^{26}$ and Elsevier, 2006; and two in London, $2002^{27}$ and $2003^{28}$.

After his return to Indonesia, Shihab was assigned in 1984 as lecturer at the Ushuluddin Faculty and Faculty of Postgraduate Studies, Syarif Hidayatullah Institute of Islamic Studies (now: State Islamic University) in Jakarta. ${ }^{29}$ On the other hand, Wahyudi did not immediately return to Indonesia after earning his Ph.D. degree, but became a Visiting Scholar at Harvard Law School (2002-2004), a member of the American Association of University Professors (since 2004) and a professor at Tufts University, Medford, MA, USA (2004-2005). ${ }^{30}$ Shihab is also active outside the campus. He is believed to have held various positions, including the Chair of the Central Indonesian Ulama Council (MUI) (1984-...), member of the Lajnah Pentashih Al-Quran, Ministry of Religious Affairs (1989...); member of the National Education Advisory Board (1989- ...), and chair of the Development Institution Management of Sharia Sciences, Management of the Consortium of the Religious Sciences of the Ministry of Education and Culture; and Assistant General Chair of the Indonesian Muslim Scholars Association (ICMI).$^{31}$ Upon his return from America, Wahyudi has become a lecturer in the Department of Comparative Islamic Legal Schools in the Faculty of Sharia, Sunan Kalijaga State

24 Yudian Wahyudi, 'Arab Responses to Hasan Hanafi's Muqaddima fi'Ilm alIstighrāb’, The Muslim World, vol. 93, no. 2 (2003), pp. 233-48.

25 Yudian Wahyudi, 'Ali Shari'ati and Bint Al-Shāți' on Free Will: A Comparison', Journal of Islamic Studies, vol. 9, no. 1 (Oxford University Press, 1998), pp. 35-45.

26 Yudian Wahyudi, 'Hassan Hanafion Salafism and Secularism', in The Blackwell Companion to Contemporary Islamic Thought (Oxford: John Wiley \& Sons, Ltd, 2007), pp. 257-70.

27 Y. Wahyudi, 'The Debate about the Sarfa: Pro and Against', Islamic Quarterly, vol. 46, no. 3 (2002), pp. 235-46.

28 Yudian Wahyudi, 'The Epistemology of Al-Munqidh Min Al-Dala', Islamic Quarterly, vol. 47, no. 1 (2003), pp. 19-33.

29 See 'About'; 'Biografi M. Quraish Shihab'.

${ }^{30} \mathrm{He}$ also received the Postdoctoral Program at the Library of Congress, Washington, D.C., but was not taken because he chose Harvard Law School.

31 See 'About'; 'Biografi M. Quraish Shihab'. 
Islamic University (UIN) in Yogyakarta, since 2005. ${ }^{32}$

In the midst of the above activities, Shihab was also active in scientific activities both at home and abroad. He was also active in writing and publishing articles and books. In Pelita newspaper, every Wednesday he writes in the "Pelita Hati" rubric. He also cared for the "Tafsir Al-Amanah" rubric in the Amanah two-week magazine (published in Jakarta). He was also a member of the Editorial Board of Journal Ulumul Qur'an and Mimbar Ulama Magazine (both published in Jakarta). ${ }^{33}$ On the other hand, Wahyudi initiated the establishment of the Nawesea Islamic Boarding School (2006), the Nawesea Press Islamic Boarding School (2006), Yudian W. Asmin Fellowship (a scholarship for Sunan Averrous junior high school students, since 2011), became Chair of the Al-Quran University Science Center (2007-2011), Deputy Rois Syuriah of provincial branch of the Nahdlatul Ulama (2006-2011), became Dean of the Faculty of Sharia UIN Sunan Kalijaga (2007), Tarekat founder of Tarekat Sunan Anbia (17 April 2015), rector of Sunan Kalijaga State Islamic University (since 2016), chief of regional private Islamic higher Education of Coordinator III (since 2016). Finally, he was acclaimed as President of the Asian Islamic Universities Association (11 November 2017) and the founder of the Center for Pancasila and State Defense Studies at Sunan Kalijaga State Islamic University. ${ }^{34}$

Shihab's interest in the interpretation of the Qur'an is well-founded. From an early age, 6-7 years, he has been educated with the Qur'an. He had to take part in a recitation held by his own father. Besides his father ordered him to read it, he also described many times Qur'anic stories. ${ }^{35}$ Similarly, Wahyudi had also studied the Qur'an since he was 7 years old directly under the guidance of his father. This process was strengthened because he attended the Darutta'lim Islamic elementary school. However, since his moving to State elementary school (Sekolah Dasar Negeri) 55, his salary has been less regular. He replaced the teacher's teacher until he was banished to Pondok (Islamic borading school) of Tremas, where his

32 Yudian Wahyudi, interview (17 Apr 2018).

33 See 'About'; 'Biografi M. Quraish Shihab'.

34 Decree of the Rector of UIN Sunan Kalijaga Yogyakarta Number 143 in 2017 on August 8, 2017.

35 See 'About'; 'Biografi M. Quraish Shihab'. 
interest in the Qur'an grew again. ${ }^{36}$ Shihab wrote many works in the field of interpretation, such as Pengantin Al-Quran, "Membumikan" Al-Quran, ${ }^{38}$ Wawasan Al-Quran ${ }^{39}$ and Tafsir al-Mishbah. ${ }^{40}$ On the other hand, Wahyudi presented, among others, "The Challenge of the Qur'an: A Western Perspective" (Sydney, Australia, 1997) and "The Debate about the Sarfa: Pro and Against" (San Francisco, USA, 1997) ${ }^{41}$ and wrote a dissertation "'The Slogan' Back to the Qur'an and the Sunna" whose third chapter is "The Hermeneutics of the Return to the Quran and the Sunnah".

\section{Comparative Interpretations of Key concepts in Q. 2: 30-38}

Now we enter the similarities and differences between Shihab and Wahyudi in understanding Qur'an, 2: 30-38 with direct implications for practical life. The story of the dialogue between God and the angels as recorded in the verses, according to Shihab ${ }^{42}$ and Wahyudi, ${ }^{43}$ is a real event: not symbolic, but actually happened. However, Shihab focuses more on așälah (authenticity) or al-ma'nāa al-awwal (original meaning) and gives less opportunity to its contemporary significance. On the contrary, Wahyudi does not question the original meanings of the theological, transcendental, spiritual, abstract and theoretical aspects of the verses, specifically related to the word khalifah. He tries to relate this term to natural, human, material, concrete-practical-operational dimensions, so that they become experimental, operational andpractical teachings. ${ }^{44}$

36 Yudian Wahyudi, interview (17 Apr 2018).

37 M. Quraish Shihab, Pengantin Al-Qur'an Kalung Permata buat Anak-Anakku (Jakarta: Lentera Hati, 2007).

38 M. Quraish Shihab, Membumikan Al-Qur'an (Bandung: Mizan, 2002).

39 M. Quraish Shihab, Wawasan Al-Qur'an tentang Zikir dan Doa (Jakarta: Lantera Hati, 1996).

40 M. Quraish Shihab, Tafsir al-Mishbah (Jakarta: Lentera Hati, 2000).

41 Then published in Yudian Wahyudi, "The Debate about the Sarfa: Pro and Against”, Islamic Quarterly, vol. 46, no. 3 (2002), pp. 235-46..

202.

42 M. Quraish Shihab, Tafsir al-Mishbah, vol. 1 (Jakarta: Lentera Hati, 2002), p.

43 Yudian Wahyudi, interview (17 Apr 2018).

44 This is a central theme in Wahyudi's writings such as Yudian Wahyudi, Maqashid Syari'ah dalam Pergumulan Politik: Berfilsafat Hukum Islam dari Harvard ke Sunan Kalijaga, Cet. 2 edition (Yogyakarta: Pesantren Nawasea Press, 2007); Yudian Wahyudi, 
The verses, said Shihab, begin with the delivery of God's decision to the angels about His plan to create humans on earth. This submission is important because they will be given various tasks related to human beings, such as maintaining, guiding and recording their charity. Afterwards, they will also thank God for being appointed as khalifah. ${ }^{45}$ On the other hand, Wahyudi looks more at this verse in the perspective of applicative operational principles. Wahyudi said, "Appointment of professional functional positionsmust go through various stages: registration of proposals by sponsors or proposers that must containminimum-contents, objectives, authority, competence, distinction, territory and budgeting as well as organising committee in order to get a technical and legitimate."46

Shihab explores the meaning of angels. In a different way, Wahyudi only sees the "practical meaning" as follows. Angels, according to Shihab, are plural of the word malak. This word is taken both from 'alaka and la'aka that means sending or delivering something. So, angels are God's messengers for various tasks. In the language of religion, angels are spirits created by Allah from light that can be shaped in various forms, obeying His commands and not in the slightest disobedience. They are blessed by God for their obedience and ability to do hard work. ${ }^{47}$ Meanwhile, Angels here, according to Wahyudi, better describe symbolically the function of their "earth" as an assembly: a source of legitimacy through a fit and proper test, competency tests, such as the people's representative council, selection commission and jury. ${ }^{48}$

Even angels, said Shihab, questioned God's will of creation of the khalifah because they suspected that he would destroy and shed blood. This angelic guess is due to three possibilities. First, it is biased because of their previous experience. Secondly, it could be because they assumed that because the person who would be assigned to be khalifab was not one of them, the coming creature might be different from them, always be

Ushul Fikih versus Hermeneutika: Membaca Islam dari Kanada dan Amerika, Cet. 4 edition (Yogyakarta: Pesantren Nawesea Press, 2007).

\footnotetext{
45 Shihab, Tafsir al-Mishbah, 1: 171.

46 Yudian Wahyudi, interview (17 Apr 2018).

47 Shihab, Tafsir al-Mishbah, 1: 173.

48 Yudian Wahyudi, interview (17 Apr 2018).
} 
exalted and worshiped. Third, he can be born from naming khalifab itself. This word impresses the 'dissolution of disputes and law enforcement,' so that surely there might be disputes between them and bloodshed. However, all this is only a guess - only God knows. Angels only asked, not protested. ${ }^{49}$ On the other hand, Wahyudi symbolises angels as "legitimate assemblies" for a project. This board of competency examiners is usually perfectionist, moralist and idealistic (tasbih and tahmid), so that they would have first underestimated incoming proposals. The assembly might always be measured with its subjectivity to the exclusion of objective standards. ${ }^{50}$

The Quran, said Shihab ${ }^{51}$ and Wahyudi, ${ }^{52}$ mentions the word khalifah only twice: Qur'an, 2: 30 concerning the Prophet Adam and Qur'an, 38: 26 concerning the Prophet David. Literally, the khalifab in the two verses above, according to Shihab, means "someone who replaces (someone else)or who comes before." ${ }^{53}$ It comes from the word khalf (back). ${ }^{54}$ On the other hand, one of its meanings, according to Wahyudi, is a person who is able to manage khiläf (mistakes) and ikhtiläf(diffence, diversity, plurality), so he has the right to continue, represent and even replace. If not able, the place is behind (khalf). ${ }^{55}$ Shihab then concluded that it has two meanings. The first meaning is a substitute of Allah in upholding His will, but not because Allah is incapable or makes human beings act as God. Instead, God intends to test them and give them honor. The second is to replace other beings who inhabit this earth. ${ }^{56}$ The word khiläf, according to Wahyudi, can also be used to refer to a mistake and weakness because, basically, a wrong person is in a weak condition. It can also mean negative potential emerging from these differences. Every

49 Shihab, Tafsir Al-Mishbah, 1: 171.

50 Yudian Wahyudi, interview (17 Apr 2018).

51 Shihab, Tafsir al-Mishbah, 1: 142-3.

52 Yudian Wahyudi, interview (17 Apr 2018).

53 Shihab, Tafsir al-Mishbah, 1: 142-3.

${ }^{54}$ M. Quraish Shihab, Tafsir al-Mishbah, vol. 11 (Jakarta: Lentera Hati, 2002), p. 482; M. Quraish Shihab, Tafsir al-Mishbah, vol. 12 (Jakarta: Lentera Hati, 2002), pp. 132-3.

55 Yudian Wahyudi, Khalifah and Khilafah in the Context of the NKRI Based on Pancasila (Jakarta, 8 Mar 2018), p. 1.

56 Shihab, Tafsir Al-Mishbah, 1: 143. 
difference must have the potential to create a split, and then weakness. ${ }^{57}$

The khalifah, said Shihab further, is someone who is given a position by God to manage a certain region. He is obliged to create a society that has good relations with God. The harmonious life of his society, religion, reason and culture are maintained. ${ }^{58}$ Thus, he according to Wahyudi, must be able to solve problems, and therefore, he must fulfill certain requirements for the field or position he chooses himself. ${ }^{59}$ Furthermore, Qur'an, 2: 30, according to Shihab, shows that the kbilafab (leadership) consists of the authority bestowed by Allah to the creature given the task, namely the Prophet Adam and his descendents, and the area of duty, namely the earth. ${ }^{60}$ However, the khilafah here does not always have to be kbiläfah Islamiyah (Islamic caliphate), but the government in the general sense, because this verse tells about the development of early human resources. ${ }^{61}$

Shihab concentrates on comparing the worthiness of the angels with that ofhuman beings to become caliphs. The angels suspected that the world was built only with tasbih (purifying Allah's substance, attibutes and deeds from all that is not suitable for Him) and tabmid (praising Allah for all the blessings He bestows on angels). ${ }^{62}$ Shihab says, "You should pay attention that the angels purify themselves by saying: "We also sanctify ourselves according to the abilities that You have bestowed on us. What we have done is for You." ${ }^{\text {63 }}$ However, for Wahyudi, this is the stage when the assembly criticized Adam's proposal to become a caliph for being a negative suggestion. Here the assembly uses its own subjectivity and standards (long experience), so it does not know the advantages of this project. Allah (sponsor, proposer) asserted that He knew more about the advantages of this proposal: asking for a scheduled re-discussion of the

57 Wahyudi, Khalifah and Khilafah in the Context of the NKRI Based on Pancasila, p. 1.

58 Shihab, 'Membumikan' Al-Qur'an, p. 166.

59 Wahyudi, 'Khalifah and Khilafah in the Context of the NKRI Based on Pancasila'.

${ }^{60}$ Shihab, 'Membumikan' Al-Qur'an, p. 166; Shihab, Tafsir al-Mishbah, 1: 142-3.

${ }^{61}$ Wahyudi, 'Khalifah and Khilafah in the Context of the NKRI Based on Pancasila', p. 1.

${ }^{62}$ Shihab, Tafsir al-Mishbah, 1: 172.

${ }^{63}$ Ibid. 
proposal. The proposal will be completed and presented in the assembly. ${ }^{64}$ Shihab ${ }^{65}$ and Wahyudi ${ }^{66}$ agree that the names here are sciences. Human beings, continued Shihab, were given the ability to know the names, functions and characteristics of objects (such as fire and wind) and the potential for language. This knowledge and potential are both condition and main capital for managing the earth. Even if human beings would persevere in bowing, prostration and worship to Allah, like what the angels would have done, the human caliphate would fail if it was practiced without knowledge. The earth is not managed solely by the tasbịh and tahmīd, but by science and practice. ${ }^{67}$ For Wahyudi, science is indeed the biggest (strongest) adaptation tool in the world, not religion. ${ }^{68}$ That is why the first word of the first revealed five Qur'anic verses is iqra' (Read!). In fact, Wahyudi emphasizes that 'reading' (qirä'ab) is a miracle unfolded in the Qur'an throughout the ages. ${ }^{69}$

Shihab still revolves around explaining the word asmä' ("names") in the context of human beings versus angels. The angels are indeed holy beings who do not know sin, but they are not capable of being caliphs because an officer must know things (names) related to his duties. The angels did not know, while Adam knew that he was entitled to become a khalifah. ${ }^{70}$ However, Wahyudi, unlike Shihab who stops at literal meaning, links these names directly to socio-political facts. He divides these names into two categories: civil and military. Civil 'names' refer to academic degrees of social professionals, such as graduates of legal studies, scholars of education, doctors, architects, religious scholars and drivers. On the other hand, military names constitute ranks (such as colonel and general) and devices (such as bombers, guns and tanks). These names cause human beings to "win a match" as the second condition

\footnotetext{
${ }^{64}$ Yudian Wahyudi, interview (18 Apr 2018).

${ }^{65}$ Shihab, Tafsir al-Mishbah, 1: 173.

${ }^{66}$ Yudian Wahyudi, interview (18 Apr 2018).

${ }^{67}$ Shihab, Tafsir al-Mishbah, 1: 173; 183.

${ }^{68}$ Yudian Wahyudi, 'Ilmu adalah Alat Adaptasi Terbesar', Republika (24 Jun 2019).

69 Yudian Wahyudi, 'Iqra' sebagai Mukjizat Terbesar Al-Quran', Kedaulatan Rakyat (14 May 2016).

70 Shihab, Tafsir al-Mishbah, 1: 180.
} 
to become a caliph. ${ }^{71}$

Actually, the command delivered to the angels in Qur'an, 2: 31 (i.e. "Tell Me the names of these [things] if what you say is right') is, according to Shihab, not an assignment to answer, but it is to prove the angel's mistake. ${ }^{72}$ Their answer not only acknowledges that they do not know the answer to that command, but also at the same time refers to their weaknesses and the sanctity of God from all fraud and injustice. It may be that the knowledge taught to Adam was not needed by the angels because it was not related to their functions and duties. ${ }^{73}$ On the other hand, Wahyudi interprets that the improvement of the proposal consists of fulfilling and strengthening the main requirements (qualifications, competencies and distinctions) (names). The proposer (God) also demonstrates the superiority of His proposal over the assembly. The assembly totally acknowledged the superiority of this new project after the proposal invited new official (i.e. Adam) to show their ability and success. The proposer also emphasized the weaknesses of the assembly which had not understood, but had punished. ${ }^{74}$

Shihab is consistent in focusing on the original meaning and the difference between inba' '(telling; giving information) and ta 'lim (teaching) in Qur'an, 2: 31. To show the ability of the khalifah to the angels, Allah, Shihab stresses, ordered, "O...Adam! Tell them the names of the objects. He says, "Please pay attention! Adam was told to 'tell' the angels, not to 'teach' to them. Teaching requires certain efforts of teacher, so that his/her teaching material can be understood by a person being taught. For such a purpose, if necessary, the teacher repeats his/her teaching until it is fully understood. Meanwhile, telling of news does not require repetition and what is reported does also not have to be understood. ${ }^{75}$ For Wahyudi, this event can be understood as a fit and proper test. Because the assembly underestimated the coming khalifah, it was asked to prove

${ }^{71}$ Wahyudi, 'Khalifah and Khilafah in the Context of the NKRI Based on Pancasila'.

72 Shihab, Tafsir al-Mishbah, 1: 173.

${ }^{73}$ Ibid., 1: 178.

74 Yudian Wahyudi, interview (18 Apr 2018).

${ }^{75}$ Shihab, Tafsir al-Mishbah, 1: 181. 
its attitudes. ${ }^{76}$ Such kind of symbolic event might also happen today in a certain political or professional life.

The word kuntum, linguistically, shows that there has been an event in the past. Shihab points out that it arises an impression that from the beginning before this dialogue has happened, there had been something the angel had not revealed. The word taktumün ('you had hidden'), on the other hand, is expressed in the form of fil mudāari (present verb). It might imply that it was done by the angels from time to time. However, we do not know what is shown in their words and actions: whether the question they asked or another one. What is certain is that God knows what is shown or hidden. ${ }^{77}$ Wahyudi interprets this stage as hidden agenda of the angelic idealists, moralists and perfectionists. They actually wanted to be recognized as better than Adam in many ways: higher in position, more honorable, smarter and more powerful. However, the proposer followed their logic, but then went beyond: He 'attacked' to break their arguments. ${ }^{78}$

God's order for the angels, in the eyes of Shihab, should not be suspended because it is a sign of obedience and surrender to God. However, the satan or devil refusesd it. Shihab says, "The devil included himself into a group of angels, so that the order was automatically directed to him too ...because he wa arrogant, i.e. ignoring and despising others while thinking of himself higher, even though the prostration (sujüd) here is prostration of respect, not worship." 79 The assembly, according to Wahyudi, was forced to be consistent by facts, so that they should leave their subyetivity towards objective and quality standards. Adam then "won the match": passed the competency test. ${ }^{80}$

Shihab ${ }^{81}$ and Wahyudi ${ }^{82}$ agree that the satan is not an angel, but jinn, - like what is affirmed by Qur'an, 18: 50. Thus, the translation of illa Iblisa abā wastakbara, according to Shihab, is "but (not except) the

\footnotetext{
${ }^{76}$ Yudian Wahyudi, interview (18 Apr 2018).

77 Shihab, Tafsir al-Mishbah, 1: 181.

78 Yudian Wahyudi, interview (19 Apr 2018).

79 Shihab, Tafsir al-Mishbah, 1: 184.

80 Yudian Wahyudi, interview (19 Apr 2018).

81 Shihab, Tafsir al-Mishbah, 1: 185.

82 Yudian Wahyudi, interview (19 Apr 2018).
} 
devil or satan was reluctant and arrogant", because the word illa here belongs to istithnā' munqati (but), not istithnā' muttasil (except). The satan felt himself better because "he was created from fire, while Adam was created from the ground" (Qur'an, 17: 61). The word istakbara here shows extraordinary arrogance because the addition of the letters, i.e. sīn and tā', to kabura (so that it becomes istakbara) serves to show "how steady and firm." 83 On the other hand, Wahyudi interprets the attitude of the satan as a symbol of senior opposition, so that he felt superior, even as oppositionism. He was well acquainted with the habits or characteristics of young officials - both because of their age or because they had just served - like Adam. The satan, Wahyudi adds, can also function to educate human beings because the more difficult the problem is, the more power people can have to solve it. Thus, the caliph becomes a problem solver, whereas the satan becomes a source of problems ${ }^{84}$

Regarding the word jannah in verse 35, said Shihab, there are two opinions: heaven in the day (the place to get reward) and a garden on earth (not in the Last Day). However, it is very unfortunate that he says, “Wherever 'paradise/heaven' or 'garden' is, it is not an important issue because that is not the main purpose of this story. What is clear, from the word jannah, is a place filled with many trees, Because of which it covers the scenery. That is the meaning of the word." ${ }^{85}$ On the other hand, Wahyudi emphasizes that jannab is twofold: garden in the world and heaven at the end of the Day. However, it here (in this verse) refers to a garden on earth. From the beginning, God planned the placement of Adam as a caliph on earth, not in the Last Day. The command of "inhabiting garden" (uskun anta wa-zanjuka al-jannata) is a horizontal movement, not vertical one, because the word uskun is horizontal movement from one place to another that is parallel. This symbolizes the movement after the inauguration - say the President of Indonesia from the House of Representatives Council and the People's Consultative Assembly (DPR / MPR) to the Merdeka Palace. The jannab in this verse is the palace: the palace as an office and official home at once. The second reason is because the Qur'an was revealed in the era of agrarian

\footnotetext{
83 Shihab, Tafsir Al-Mishbah, 1: 186.

84 Yudian Wahyudi, interview (19 Apr 2018).

85 Shihab, Tafsir Al-Mishbah, 1: 189.
} 
economics. Earth is land in the general sense, which includes, among other things, clay, sand and stone, mountains, beaches and deserts. On the other hand, it is the most fertile and productive land because it is close to water (rivers flow below) as a source of life. In all-round palace there are also budgeting and state facilities! ${ }^{86}$

However, Adam and his wife were seduced by the satan shortly after they were in heaven, so they were expelled from their original state, even expelled to earth as a result of the violation. The meaning of mimmā $k \bar{a} n \overline{\mathbf{a}} \overline{\mathrm{r}} h$, according to Shihab, is pleasure and such a high position on the side of the Divine presence. The word mata $\bar{a}$ in essence is the pleasure of using something in a limited time, disjointed; there are shortcomings and some are better in terms of quality and quantity. The world and its enjoyment are temporary; there is an eternal place, there is a very quality eternal enjoyment on the Last Day. ${ }^{87}$ On the Day of Judgment, Shihab adds, there was also a very long time of misery (for people who were big sinners).$^{88}$ Wahyudi see this again differently. Here, in verse 36 , they (Adam, wife and devil) are examined for their accountability. During this examination, they defended themselves and attacked each other. As a consequence, Adam was removed from his position as caliph. He had also to become a common citizen ( $f$ al-ardi). Because all state facilities were revoked, he and his wife had to search for themselves, with all their bitter bits, even though they were originally all available (matā $).{ }^{89}$

The expulsion from a heaven that is full of pleasure, said Shihab, should encourage Adam and his wife to try to go back there - like the way God will show it. ${ }^{90}$ The reception or meeting was very encouraging for Adam because the addition of the letter $t \bar{a}$ ' in the word laqa (so that it becomes talaqqa) gaives meaning of happiness and pleasure in terms of that acceptance. The addition indicates that the acceptance or meeting was preceded by effort and seriousness. Here God inspires that there is a sincere regret from his heart and words of prayer as read in Q. al-A'rāf (7): 23. These sentences can also be understood as forgiveness from

\footnotetext{
86 Yudian Wahyudi, interview (20 Apr 2018).

87 Shihab, Tafsir al-Mishbah, 1: 193.

88 Ibid., 1: 190-1.

89 Yudian Wahyudi, interview (20 Apr 2018).

90 Shihab, Tafsir al-Mishbah, 11: 194.
} 
Allah to Adam and his partner. ${ }^{91}$ For Wahyudi, this phase is the stage where Adam's mistakes have been proven. As an official who violates the rules, Adam signs the minutes of inspection and is committed not to repeat the same mistakes. Here Adam was relieved that his improvement efforts were accepted, but it was odd to be told to descend from jannah (the position of caliph), as shown below. ${ }^{92}$

The rrder to go down is mentioned twice because, according to Shihab, to remove the possibility of misunderstanding that the command of descending from the jannah is only from one level to a lower one, but still remained in the heaven. Therefore, the order this time reads: "Come down from it all" as an affirmation that you all, not just the tempter, must go down. ${ }^{93}$ This repetition can also be used to explain two different things. The first is that the order implies to going down to earth, the place to eat, drink and be hostile. The second command is to signal the decline of satan's religious dignity as a result of defying God by tempting Adam and his wife. On the other hand, the dignity of Adam and his wife was due to following the seduction of the satan. ${ }^{94}$ The second command, for Wahyudi, was the removal of the position of caliph from Adam because his violation was severe. This was a continuation of the first fall, which was temporary: being disabled due to the need for inspection, but has not been removed. All people in the palace (Adam, wife and satan) was returned to the community. Repentance was accepted, but they were still told to go down (removed). So, the phrase ila hin here can be interpreted as a waiting period until the legal sentence/pinalty. It can also mean 'term': officials who fall can return as long as they win again. ${ }^{95}$

Shihab ${ }^{96}$ and Wahyudi ${ }^{97}$ agree that Adam's sin is lighter in comparison to satan's sin because Adam slipped, while satan did it with full awareness and arrogance. However, for Wahyudi, Adam's sin was a big $\sin$ if it was associated with his 'oath of office' because Adam violated his

91 Shihab, Tafsir al-Mishbah, 1: 195.

92 Yudian Wahyudi, interview (20 Apr 2018).

93 Shihab, Tafsir al-Mishbah, 1: 200.

94 Ibid.

95 Yudian Wahyudi, interview (20 Apr 2018).

96 Shihab, Tafsir Al-Mishbah, 1: 191.

97 Yudian Wahyudi, interview (21 Apr 2018). 
highest main dutiy and function. Here Adam opposed the state, against the constitution, with various possibilities such as willing to take office forever (L'Etat c'est moi) and corruption. In Islam, there are three great temptations: throne (power), wealth and sex. Of the three temptations Adam was tempted by power at most, so that it wiould make it easier to gain wealth (such as monopoly and corruption of state assets), not sex. Indeed, he was driven by the temptation of his partner, but not having sex because they are husband and wife and in the jannah on earth (temporary place). Eve can be better described here as first lady, whose main desire was luxury (wealth). So, Adam's mistake was to obey his wife's whining to get property. Indeed, accumulating wealth was one of the main ideals of young officials like Adam. ${ }^{98}$

\section{Political Implications}

The Qur'an uses the word khalifah, according to Shihab, to refer to people who are given the authority to manage the territory, both broad and limited. David manages Palistina and its surroundings, while Adam, potentially or actually, manages the totality of the earth at the beginning of the history of humanity. ${ }^{99}$ Still for him, the caliphate contains three main elements, namely: first, man, the caliph; second, territory, that is what is referred to by the word ard in the verse; and third, the relationship between the two elements. Outside of all three there are also those who confer the task of the caliphate. The assigned (caliph) must adjust all his actions with the mandate of the assignor. ${ }^{100}$ In short, the main task of the caliph, according to Shihab, is to prosper or build the earth in accordance with the concept of the assignor (Allah SWT). ${ }^{101}$ For Wahyudi, the caliph is a person who must fulfill the qualifications and competencies for the field he leads. This is the position of kifäyah (i.e. a position that must be gained by a person(s) as representative(s) of a community), not 'ayn (i.e. a postion that is must be taken by everyone). Everyone is a leader, but the field of leadership depends on the choice of each person. Its territory

\footnotetext{
98 Ibid.

99 Shihab, Tafsir al-Mishbah, 12: 133.

100 Ibid., 12: 134.

101 Shihab, Membumikan' Al-Qur'an, p. 172.
} 
does not have to be a political power: it can be any field. ${ }^{102}$

A caliph, according to Shihab, has the potential, even actually, to make mistakes due to following the passions. Therefore, both Adam and David were reminded not to follow the passions (Qur'an, 20: 16 and Qur'an, 38: 26). ${ }^{103}$ Adam's fall, according to Wahyudi, describes the fall of young officials (whether because of age or because they were first in office) who, first, had many theories but lacked experience; second, feeling great for being able to defeat the authority and power determinants; third, feel they have a backing (Allah in the case of Adam); fourth, his ears are deaf (do not want to hear advice from others); fifth, tempted whisperer (wife in the case of Adam). Thus, sixth, dare to violate the constitution. ${ }^{104}$

The Quran, according to Shihab ${ }^{105}$ and Wahyudi, ${ }^{106}$ never mentions the word kbiläfah. It only mentions the khalifah (person/official) with plural khulafä and khalä if, not khilafah (as a political system, such as the kingdom or republic). However, why were there khiläfah in the history of Islam? Shihab does not provide a direct answer to this question. He accepts it as a fact that is taken for granted as God's promise to those who believe and do good deeds. ${ }^{107}$ Unlike Shihab, Wahyudi mentions it. The Prophet Muhammad fulfilled the requirements for a caliph. First, he won the match. The liberation of Mecca was the first unbloody revolution in history. Why did the Messenger of Allah win the match? Because he was surrounded by the 'names' (asmā). The 'names' here were neither Abu Bakar, nor Umar, nor Alin, nor Khalid bin Walid, nor Wakhshi, but their professions: mujähidin, i.e. the army. They mastered the 'names' of the highest military technology of the 7th century AD. Among others, there were swords, arrows, spears, camels, horses, hills (heights). Because they were very well trained and in very large numbers, Abu Sufyan, as

102 Yudian Wahyudi, interview (17 Apr 2018).

103 Shihab, Tafsir al-Mishbah, 12: 133.

104 Wahyudi, 'Ilmu adalah Alat Adaptasi Terbesar'.

105 Shihab, Tafsir al-Mishbah.

106 “Jalan Panjang Pembubaran Ormas” (Jakarta: Metro TV, 2017), https:// www.youtube.com/watch?v=8AK4r67QH9A; "Indonesia Bicara: Pembubaran Ormas Radikal \#2 “(Jakarta: TVRI, 2017), https:/ /www.youtube.com/watch?v=S-L_QyyvkJ4.

107 Shihab, Tafsir al-Mishbah, 1: 180. 
the leader of Mecca, was better to surrender. ${ }^{108}$

Whayudi raised the following question: "Why did Abu Bakr become the caliph (successor in the field of government, not in the field of prophethood) after the Prophet died?" He replies himself, "It was because Abu Bakr won the match. Abu Bakar was promoted by Umar and no one resisted. Why did Umar become a caliph after Abu Bakr? The answer is because he won match. Umar was promoted by Abu Bakr and then accepted by acclamation. Why did Usman become caliph after Umar? The answer is because he won match. Usman was chosen by a team of six people. Why did Ali become the caliph to replace Usman? The answer, is that he won match. Ali was also chosen by a team of six people. Why did Hasan become caliph after Ali? The answer is also winning match. Hasan was appointed his father (Ali) before his father died. Why did Muawiyah become caliph after Hasan? The answer is the same, i.e. winning match. Through the peace treaty (Am al-Jama' $a b)$, Hasan handed over the Caliphate to Muawiyah, so that he became caliph. Last, but not least," Wahyudi asked himself, "Why was the Caliphate dissolved in 1924? The answer is because it losed match. The Ottoman Empire as the last Muslim superpower was beaten in World War I (1918) because its 'names' - specifically, military technology - were out of date and it was also betrayed by Saudi Arabia (even though the Ottoman Empire was in coalition with Germany and Hungary, two Christian countries). After participating in destroying Ottoman Empire, the people of Saudi Arabia actually established a kingdom, not a khiläfab!"109

\section{E. Concluding Remarks}

From this comparative study we might conclude the following aspects. First, Quraish Shihab and Yudian Wahyudi are interested in interpreting Qur'an 2: 30-38. However, their motivations are quite different. Shihab's interpretation of these verses constitutes part of his project of the interpretation of the whole Qur'an, whereas Wahyudi interprets them mostly because he is willing to respond critically to the idea of re-building al-Khiläfah al-Islamìyah (Islamic Chaliphate) proposed

108 Wahyudi, Suka News Latter, p. 8.

109 Wahyudi, 'Khalifah and Khilafah in the Context of the NKRI Based on Pancasila', pp. 1-2. 
by Hizbut Tahrir Indonesia (HTI). Second, even though both agree that all Qur'anic stories, including the story of the creation of Adam, consist of moral teachings (ibrab; plural: ibar), they are different in making sense of the verses. Unlike Shihab who focuses more on the original meanings of the key concepts of the verses, Wahyudi emphasizes more on their symbolic meanings, so that they can be easily applied for the goodness (maslahab) of human life. Third, both agree that the verses (especially verse 30) cannot be used as argument for the re-establishment of al-Khiläfah al-Islamiyah in a narrow sense. For shihab, they refer to the political leadership in general from Adam to the Last Day. In a different way, Wahyudi affirms that they refer to all professional positions that are related to human life. 
Quraish Shihab’s and Yudian Wahyudi's Interpretations Q. 2: 30-38

\section{BIBLIOGRAPHY}

'About', Muhammad Quraish Shibab Official Website, http:/ quraishshihab. com/about/, accessed 30 Jan 2017.

'Biografi M. Quraish Shihab', Tafsir Al-Mishbah-M. Quraish Shihab, 27 Dec 2010, https:/ / tafsiralmishbah.wordpress.com/biografi-m-quraishshihab/, accessed 1 Feb 2017.

al-Dāmaghānī, al-Husayn ibn Muhammad, Ișlāḥ al-Wujūh wa al-Naz̧àìr, Beirut: Dar al-'ilm, 1970.

Indonesia Bicara: Pembubaran Ormas Radikal \#2, Jakarta: TVRI, 2017, https://www.youtube.com/watch?v=S-L_QyyvkJ4.

Jalan Panjang Pembubaran Ormas, Jakarta: Metro TV, 2017, https://www. youtube.com/watch?v $=8 \mathrm{AK} 4 \mathrm{r} 67 \mathrm{QH} 9 \mathrm{~A}$.

Shihab, M. Quraish, Wawasan Al-Qur'an tentang Zikir dan Doa, Jakarta: Lantera Hati, 1996.

----, Membumikan Al-Qur'an, Bandung: Mizan, 2002.

----, Tafsir al-Mishbah, vol. 1-12, Jakarta: Lentera Hati, 2002.

----, Pengantin Al-Qur'an: Kalung Permata buat Anak-Anakku, Jakarta: Lentera Hati, 2007.

Wahyudi, Yudian., 'The Debate about the Sarfa: Pro and Against', Islamic Quarterly, vol. 46, no. 3, 2002, pp. 235-46.

----, 'Ali Shari 'ati and Bint Al-Shātị' on Free Will: A Comparison', Journal of Islamic Studies, vol. 9, no. 1, Oxford University Press, 1998, pp. 35-45.

----, 'The Slogan "Back to the Qur'an and the Sunna" : A Comparative Study of the Responses of Hasan Hanafi, Muhammad 'Abid alJabiri and Nurcholish Madjid', PhD. Dissertation, Montreal: McGill University, 2002.

----, 'Arab Responses to Ḣasan Ḣanafi's Muqaddima fi'Ilm al-Istighrāb’, The Muslim World, vol. 93, no. 2, 2003, pp. 233-48 [https://doi. org/10.1111/1478-1913.00022].

----, 'The Epistemology of Al-Munqidh Min Al-Dala', Islamic Quarterly, vol. 47, no. 1, 2003, pp. 19-33.

----, 'Hassan Hanafion Salafism and Secularism', in The Blackwell Companion 
M. Djidin \& Sahiron Syamsuddin

to Contemporary Islamic Thought, Oxford: John Wiley \& Sons, Ltd, 2007, pp. 257-70.

----, Maqashid Syari'ah dalam Pergumulan Politik: Berfilsafat Hukum Islam dari Harvard ke Sunan Kalijaga, Cet. 2 edition, Yogyakarta: Pesantren Nawasea Press, 2007.

----, UshulFikih versus Hermeneutika: Membaca Islam dari Kanada dan Amerika, Cet. 4 edition, Yogyakarta: Pesantren Nawesea Press, 2007.

----, Perang Diponegoro: Tremas, SBY dan Ploso, 3rd edition, Yogyakarta: Pesantren Nawesea Press, 2014.

----, Dari McGill ke Oxford Bersama Ali Shari'ati dan Bint al-Shati, 2nd edition, Yogyakarta: Pesantren Nawesea Press, 2016.

----, 'Iqra' sebagai Mukjizat Terbesar Al-Quran', Kedaulatan Rakyat, 14 May 2016.

----, Jihad Ilmiah Dua: Dari Harvard, Yale, dan Princeton, 4th edition, Yogyakarta: Pesantren Nawesea Press, 2017.

----, Jihad Ilmiah: Dari Tremas ke Harvard, 4th edition, Yogyakarta: Pesantren Nawesea Press, 2018.

----, Khalifah and Khilafah in the Context of the NKRI Based on Pancasila, Jakarta, 8 Mar 2018.

----, 'Ilmu adalah Alat Adaptasi Terbesar', Republika, 24 Jun 2019. 